\title{
Land Tenure and Its Influence on Agriculture in Artisanal Gold-Mining Zones of Sikasso Region, Mali
}

\author{
Mahamadou Moussa Keita1,2,3* , George Morara Ogendi ${ }^{2,3}$ \\ ${ }^{1}$ Rural Polytechnic Institute for Training and Applied Research, Katibougou, Koulikoro, Mali \\ ${ }^{2}$ Department of Environmental Science, Egerton University, Njoro Campus, Nakuru, Kenya \\ ${ }^{3}$ Dryland Research Training and Ecotourism Centre, Chemeron, Baringo, Kenya \\ Email: *mahamadou77@yahoo.fr, gmorara2009@gmail.com
}

How to cite this paper: Keita, M.M. and Ogendi, G.M. (2021) Land Tenure and Its Influence on Agriculture in Artisanal GoldMining Zones of Sikasso Region, Mali. Open Journal of Ecology, 11, 95-104. https://doi.org/10.4236/oje.2021.112009

Received: December 14, 2020

Accepted: February 4, 2021

Published: February 7, 2021

Copyright $\odot 2021$ by author(s) and Scientific Research Publishing Inc. This work is licensed under the Creative Commons Attribution International License (CC BY 4.0).

http://creativecommons.org/licenses/by/4.0/ (c) (i) Open Access

\begin{abstract}
Land tenure is a major determinant of the types of land use in a region or area and, by extension, affects its conservation. Most of the land that falls under public or communal land-tenure systems in developing countries such as Mali faces numerous challenges among them being natural resource overexploitation. This is mainly because the land is openly accessible to all people around it, and thus the tendency to overexploit the land resources leading to degradation, and food and environmental insecurity. In Mali, land ownership falls under three categories: Public or Government, Communal and Private. This study was undertaken to assess the land ownership types in Yanfolia District, Mali, a gold-mining area that lies some $170 \mathrm{~km}$ southern east of capital district of Bamako and upstream of Selingué dam on Sankarini River. A social survey of 200 households was done using a structured questionnaire. Additional research instruments were focus group discussion, key informant interviews and observation check-lists. The data was analyzed using both descriptive and inferential statistics. The study findings indicated that most of the land under gold-mining was owned by the government followed by community and finally private. There were significant associations between size of land under gold-mining and land tenure types: communal land $\left(\chi^{2}=\right.$ 30.52; $\mathrm{p}=0.000)$; private land $\left(\chi^{2}=65.09 ; \mathrm{p}=0.000\right)$ and public or government land $\left(\chi^{2}=177 ; \mathrm{p}=0.000\right)$. Gold-mining takes place mostly on lands classified under public/government and communal compared to that which takes place on lands classified as private. It is recommended that the relevant Malian governmental regulatory and enforcement agencies implement and enforce existing environmental laws with respect to land and environment. These agencies should adopt participatory and sustainable approaches to land
\end{abstract}


and natural resources management for improved food and environmental security.

\section{Keywords}

Land, Gold-Mining, Environment, Agriculture, Food-Security

\section{Introduction}

Land use as a common natural resource has jeopardized environmental security and property right in developing countries [1]. Artisanal gold-mining contributes to raising land ownership problems in Mali. Majority of artisanal gold-mining is exploited as common resources under the property right of community. Land right is declining to be for government generally in Mali [2] [3]. Indeed, there are two other property rights which include community and private. In fact, artisanal gold mining exploitation is under community right in term of common resources in this country. There is an exploitation type called "draguage" (excavator system) which is used by private firms contracted privately by the government of Mali. These private firms exploit gold directly on rivers and backwaters with government licenses or authorization over the country. Land monitoring in Mali is carried out by three types of right. The first right is for government which includes all in the territory of country, aspects of defense, and questions linked to boundaries and community conflict. The second right is about the traditional laws and rights of communities. These are usually called accustomed laws and rights. In other words, they are first occupants, habitants and comers at the place. Ordinarily, these rights and laws are followed up and monitored by traditional chief of villages, sub-counties and counties undertaking the government right. This study was undertaken to assess the land ownership types of artisanal gold mining area of Farabacoura, Yanfolia District in Mali.

\section{Materials and Methods}

\subsection{Study Area}

Sikasso region is located in the Southern part of Mali and it is also the third administrative region of the country. It borders Segou region to the North, Republic of Cote d'Ivoire in the South, Republic of Guinea to the West, Burkina Faso to the East and Koulikoro region to the North West. Sikasso region covers $71.790 \mathrm{~km}^{2}$ representing $3.8 \%$ of national territory. The region has seven (7) districts which include Sikasso, Bougouni, Kadiolo, Kolondièba, Koutiala, Yanfolila and Yorosso. In Sikasso region, there are 3 urban communes, 144 rural communes and 1.831 villages [4].

Farabacoura and Tiéguècourouni are villages in Tangandougou commune, district of Yanfolila in Sikasso region. Tangandougou commune is some $170 \mathrm{~km}$ from Bamako, the capital city of Mali. The study sites, Farabacoura are about 10 
$\mathrm{km}$ from Selingué Dam which is on Sankarani River while Tiéguècourouni is 55 $\mathrm{km}$ away from Selingué. The population of the commune is about 5775 inhabitants [5]. The major ethnic groups of the natives are composed of Bambara, Senufo, Manliké, Bozo and Peulh (Figure 1).

The economic activities of the commune include crop and livestock production, fishing, agroforestry, commerce and artisanal gold-mining. These production systems are characterized by small-scale farming with low agricultural production. In term of cereals production, these small-scale farmers cultivate maize, sorghum and millet for subsistence purposes. The commercial crops include rice, cotton, groundnut and sweet-potatoes.

Livestock production is based both on extensive system for commercial purposes and traditional practices for the provision of households needs and to supply crop production with composting manure and other activities in farm. The main types of livestock reared comprise cows, goats, sheep, donkeys and chickens. They are only reared for subsistence purposes and for other domestic expenditures such as health care and for traditional ceremonies like marriages, burial and other rites of passages.

In term of forest and environmental management, the natives practice agroforestry activities mainly focused on both indigenous and exotic trees. The exploitation of the indigenous plants such as karité, néré, baobao, Afzelia africana, Khaya senegalensis and Prosopis africana is for food production, precious wood and medicinal purposes. The communities also grow fruits trees such as orange, mango and papaya among others where they supply the local markets with fruits as a source of income apart from supplementing their diets.

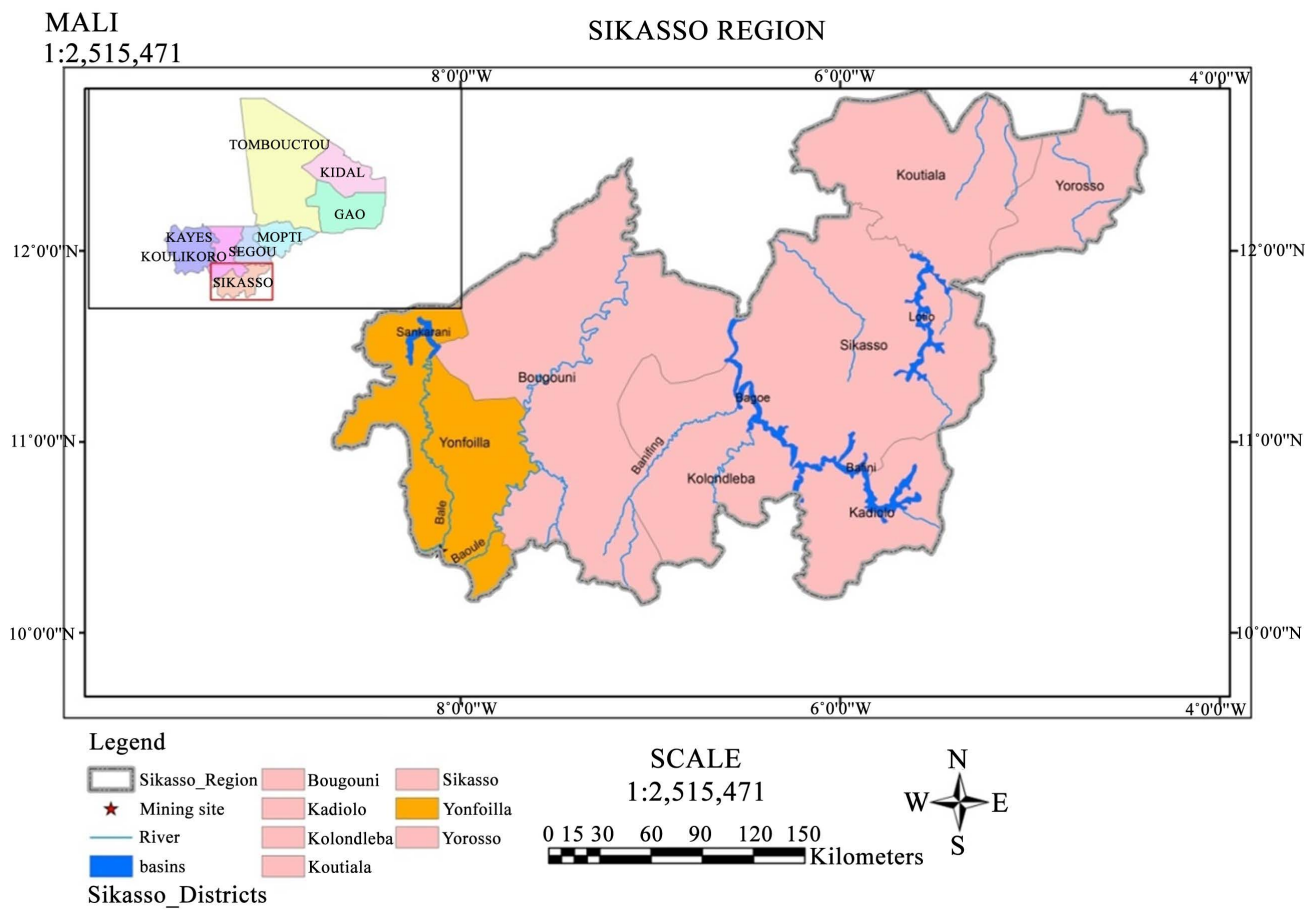

Figure 1. Location of study area in Sikasso region. 


\subsection{Assumption of System Theory}

The system theory stands for ecosystem and socio-system in term of entities' relationships. The ecosystem has to ensure interacting functional unit in living and non-living environment while socio-system refers to humans' functional unit exploiting resources for their lives, they are supposed to protect and improve them from destruction state. The imbalance between entities in their functional units will drive to climate change in environment, society and economic activities. Consequently, the imbalances of entities will impact sustainable development logical process to be realized in multidimensional context [6]. The approach focuses on the system model of Drivers-Pressures-State-Exposure-Effects-Actions (DPSEEA) inspired from Drivers, Pressures, State, Impacts, Responses (DPSIR) [7] [8].

\subsection{Data Collection Tools and Methods}

Structured questionnaires were used to gather information from the household head or his/her representative. The questionnaires were structured on professions (gold mining, crop, livestock, agroforestry, fisheries, age, gender, origin, marital status, education level, etc.). In addition, three focus group discussions were held with local government, miners and non-miners in Tangandougou Commune plus key informant interviews and observation check-list. The collected data was analysed using the Statistic Package for Social Sciences (SPSS) while ArcGIS was used for geographical information to come up with study area Map.

The sampling technique that was employed in this study considered artisanal gold mining as a factor that caused impacts on social economic functions of the natives of Sikasso region. Data was collected by the use of structured questionnaire which was administered through interviewing the households' heads. In each case one representative of the household who was 18 years old was interviewed. The sample size was 200 households consisting of respondents drawn from the study area and had some information about artisanal gold mining and impacts on the social economic systems. The questionnaires were administered in Farabacoura and Tieguecourouni villages both in Tangandougou Commune, of Yanfolila district.

The respondents were drawn from the two villages equally as follows:

- The mining site: Farabacoura village respondents represented the mining site. These respondents were involved in either mining and/or agricultural activities. The information on these activities was collected from an area of approximately $20 \mathrm{~km}^{2}$.

- The non-mining site: as a nearby site of Tieguecourouni village, the study interviewed 100 households by soliciting information about mining and agricultural activities based on study objectives. The distance between the two study villages was approximately $45 \mathrm{~km}$ but within the same commune.

The sample for this study was calculated using the formula indicated here be- 
low [9]. The study was used this formula, because the population of Tangandougou commune is ready known.

$$
n=\frac{N C^{2}}{\left[C^{2}+(N-1) e^{2}\right]}
$$

where:

$n=$ is the sample size

$N=$ is the known population of Tangandougou commune

$e=$ is the error margin of (3\%)

$C=$ is the coefficient of variation $(30 \%)$

The sample size based on this formula was:

$$
n=\frac{5775 \times 0.3^{2}}{\left[0.3^{2}+(5775-1) 0.03^{2}\right]}=100
$$

The result was multiplied by two giving a total of 200 households distributed as $50 \%$ between the two villages for data collection in Tangandougou commune.

The study used exploratory and descriptive research designs with cross sectional random sampling of 200 households. Data collection was done using household survey in Farabacoura and Tiéguècourouni. The questionnaires were administered on mining site of Farabacoura and non-mining site of Tiéguècourouni. This study sites were approximately $50 \mathrm{~km}$ apart. The proportionality of 100 samples was used for household survey as sample size on each site. Data was analysed using descriptive and inferential statistics such as Chi-square, correlation and logit model computed with location as dependent variable. According to [10], "the model is defined as logistic if the expression for the probability factors given the $X S$, is 1 over 1 plus e to minus the quantity $\alpha$ plus the sum from $i$ equals 1 to $K$ of $\beta_{i}$ times $X_{i}^{\prime \prime}$ the formula bellow defined mathematically Logistic Regression model.

$$
P(X)=\frac{1}{1+\mathrm{e}^{-\left(\alpha+\sum \beta_{i} X_{i}\right)}}
$$

where $P(X)$ stands for location, $\alpha$ and $\beta_{i}$ represented in the model formula are unknown parameters which have to be estimated from data collected on $X s$ and $D$ for a group of study subjects [10]. In this case study, the binary variables were used and codified as no or yes which are equal to $(0,1)$.

\section{Results}

\subsection{Descriptive of Land Ownership in Artisanal Gold-Mining}

The community land property right was observed in 167 households representing around $83.5 \%$ of study population. Those who were not working on community land were 33 respondents representing $16.5 \%$ of the interviewed people. The distribution was 69 positive responses from the non-mining site and 98 from the mining site. The negative responses were 31 from the non-mining site and 2 from mining site. The Chi-Square was $\left(\chi^{2}=30.52\right)$ with the significance level of $(\mathrm{p}=0.000)($ Table 1$)$. 
Table 1. Frequency and percentage of types of land in non-mining and mining areas.

\begin{tabular}{|c|c|c|c|c|c|c|}
\hline \multirow{2}{*}{ Parameters } & \multirow{2}{*}{ Freq. } & \multirow{2}{*}{$\%$} & \multicolumn{2}{|c|}{$\mathrm{N}=\mathbf{2 0 0}$} & \multirow{2}{*}{$\chi^{2}$} & \multirow{2}{*}{$\mathrm{p}$} \\
\hline & & & Non-Mining & Mining & & \\
\hline \multicolumn{7}{|c|}{ Community right } \\
\hline No & 33 & 16.5 & 31 & 2 & \multirow{2}{*}{30.521} & \multirow{2}{*}{0.000} \\
\hline Yes & 167 & 83.5 & 69 & 98 & & \\
\hline \multicolumn{7}{|l|}{ Private } \\
\hline No & 137 & 68.5 & 42 & 95 & \multirow{2}{*}{65.091} & \multirow{2}{*}{0.000} \\
\hline Yes & 63 & 31.5 & 58 & 5 & & \\
\hline \multicolumn{7}{|l|}{ Government } \\
\hline No & 104 & 52 & 99 & 5 & \multirow{2}{*}{177.003} & \multirow{2}{*}{0.000} \\
\hline Yes & 96 & 48 & 1 & 95 & & \\
\hline
\end{tabular}

Source: Authors' Field Survey, 2016.

The private right of land was quoted in 63 interviewed households represented by $31.5 \%$ of respondents' population. They were 137 households represented by $68.5 \%$ in which private right of land was not quoted among study population. That population was distributed as 58 from the non-mining site and 5 people from the mining site who gave the positive responses. The negative responses were 42 from the non-mining site and 95 from the mining site among observed population. The Chi-Square was $\left(\chi^{2}=65.09\right)$ with the significance level of $(p=$ $0.000)$.

The public or government right was observed in 96 interviewed households represented by $48 \%$ of the respondents' population. There were 104 interviewed households represented by $52 \%$ in which people did not recognize the public right. The distribution was 1 observed from the non-mining site and 95 from the mining site gave positive responses There were 99 from the non-mining site and 5 from the mining site who quoted the negative responses. The Chi-Square was $\left(\chi^{2}=177.00\right)$ with the significance level of $(p=0.000)$.

\subsection{Correlation of Land Property Right}

The correlation of land property right included community right, private right, government or public right and about location. Results showed that there were significant strong negative relationships between private right and location $(\mathrm{r}=$ $-0.57 ; \mathrm{p}>0.01)$, private right and community right $(\mathrm{r}=-0.65 ; \mathrm{p}>0.01)$ and between government versus private right $(r=-0.60 ; p>0.01)$. In addition, there were significant strong positive relationships between community right and location $(r=0.39 ; p>0.01)$, government right and location $(r=0.94 ; p>0.01)$ and between government versus community right $(r=0.40 ; p>0.01)$ (Table 2$)$.

\subsection{Logit Regression of Land Property Right}

Land right is declining to be under the control of the government generally in 
Table 2. Pearson's correlations of land property right.

\begin{tabular}{ccccc}
\hline Parameters & Location & Community right & Private right & Government right \\
\hline Location & 1 & & & \\
Community right & $0.391^{* *}$ & 1 & 1 & 1 \\
Private right & $-0.570^{* *}$ & $-0.656^{* *}$ & & \\
$\begin{array}{c}\text { Government/ } \\
\text { Public right }\end{array}$ & $0.941^{* *}$ & $0.400^{* *}$ & $-0.608^{* *}$ & 1 \\
\hline
\end{tabular}

**. Correlation is significant at the 0.01 level (2-tailed). Source: Authors' Field Survey 2016.

Mali (Constitution, 1992). Indeed, there are two other property rights which include community and private. Artisanal gold-mining is exploited under community right in term of common resources in this country. There is a type of exploitation called "draguage" (excavator system) which is carried out by contracted private companies with partnership of the government of Mali. These private companies are exploiting gold directly on rivers with government licenses or authorization over the country.

Land is monitored by three types of right in Republic of Mali. The first right is from the government which includes all the territory of country, all aspects of defense, questions linked to boundaries and community conflict. The second is about the traditional laws and rights of communities. These are usually called accustomed laws and rights. In other words, they are first occupants, habitants, comers at the place. Ordinarily, these rights and laws are followed-up and monitored by the traditional chief of villages, sub-counties and counties undertaking the government right (Table 3 ).

The parameters run about the property right looked at the ownership of land used on gold-mining and non-mining sites. These were attributed to community right, private right and government or public right of land. They all had a positive strong correlation to localities with the coefficient of community right (0.819), private right (0.433) and government right (7.587). If $Y=\beta_{0}+\beta X_{1}+\beta X_{2}+\beta X_{3}+\varepsilon$ so the variables in equation were $Y=-3.851+0.819+0.433+7.587=4.988$.

\section{Discussions}

There are three major types of land currently in Mali. The significant characteristic is that government owns all the land over the country in term of administration. By doing so, it becomes the principal regulator of all issues related to land [11]. The government is currently on land identification concerning farm lands in Mali. In addition, there are also private and community property rights of land that means individual or communities can get property right of land in Mali. According to [12] land certification is a fundamental issue of stability, it increases households income and reduces conflict [13]. Land conflict becomes increased where policies are not clear [14] [15]. 
Table 3. Logit regression of land tenure in tangandougou commune.

\begin{tabular}{ccccc}
\hline Explanatory Variables & B & S.E. & Wald & Sig. \\
\hline Community right & 0.819 & 1.239 & 0.437 & 0.509 \\
Private right & 0.433 & 1.027 & 0.178 & 0.673 \\
Government & 7.587 & 1.230 & 38.061 & $0.000^{\star * *}$ \\
Constant & -3.851 & 1.439 & 7.161 & 0.007 \\
\hline
\end{tabular}

*** significant at 1\% level. Source: Authors' Field Survey, 2016.

\subsection{Public/Government Land}

In the case of public land, the rights belong to the government and it is the largest flexible ownership. Globally, this right covers all territory of the country including parks, lakes, rivers, forests, swamp and dry land. The government is the regulator and controller of land under this right. These lands are notified with landed title and classification order so as to protect them such as forests, sensibly lands, army land and other protected areas [16]. These public lands have to be reclassified only by political and national interest issues [17]. According to [18] the estimation of world's forests are about 80 percent are publicly owned with the remaining held by local communities and municipalities.

\subsection{Private Land}

In case of private land, they are three kinds of documents which allowed people to own land. These documents are essentially the letter, permit and land title. The letter and permit cannot give all right of ownership while fundamental title gives all right of ownership including exploitation of natural resources. The letter and permit are temporary authorization given to owners by authorities. This ownership will be released whenever the government projects are undertaken for the same the land [19].

\subsection{Community Land}

Land under control of the community, the comminatory land is for everybody and it will fail into the "Tragedy of commons". The property right is neither for anybody nor notified and identified by any official document. Nevertheless, according to the constitution of 1992, people can exploit community land for agricultural purposes, animals grazing and housing in rural areas. Land becomes overexploited and degraded by community such us overfishing, forests degradation and deforestation [20] [21].

\section{Conclusion \& Recommendations}

The study concluded that the cultivable lands were negatively affected by artisanal gold-mining because of absence of property right in this area. Therefore, the government should identify and certify by sectors all lands over the territory of Mali. The certification will correct the insufficiency of land management and prevents conflict in rural areas. 


\section{Acknowledgements}

This material is based upon work supported by the United States Agency for International Development, as part of the Feed the Future initiative, under the CGIAR Fund, award number BFS-G-11-00002, and the predecessor fund the Fond Security and Crisis Mitigation II grant, award number EEM-G-00-04-00013.

\section{Conflicts of Interest}

The authors declare no conflicts of interest regarding the publication of this paper.

\section{References}

[1] Hardin, G. (1968) The Tragedy of the Commons. Science, 162, 1243-1248. https://doi.org/10.1126/science.162.3859.1243

[2] Republic of Mali (1992) Constitution: Presidency of the Republic of Mali.

[3] Nurbekov, A., Akramkhanov, A., Kassam, A., Sydyk, D., Ziyadoullaev, Z. and Lamers, J.P.A. (2016) Conservation Agriculture for Combating Land Degradation in Central Asia: A Synthesis. AIMS Agriculture and Food, 1, 144-156.

https://doi.org/10.3934/agrfood.2016.2.144 http://www.aimspress.com/journal/agriculture

[4] Assemblée Régionale de Sikasso (2011) Plan stratégique de développement régional de Sikasso 2011-2020. ARS/Fonds Africain pour le Développement, Abidjan.

[5] RGPH (2009) Récensement General de la Population et de l'Habitat du Mali (RGPH) Résultats définitifs. Répertoire des villages, Sikasso.

[6] Mele, C., Pels, J. and Polese, F. (2010) A Brief Review of Systems Theories and Their Managerial Applications Service Science, 2, 126-135. https://doi.org/10.1287/serv.2.1_2.126

[7] Abdelrehim, A., Ghali, C., Akol, C., Ambala, C., Mafuta, C., Sebukeera, C., Turyatunga, F., Lungu, I.G., Ndione, J.A., Opio-Odongo, J., Sabet, M., Daoud, M., and Ochola, W. (2011) Africa Environment Outlook-3, Authors' Guide. United Nations Environment Programme, Nairobi.

[8] Kleinbaum, D.G. and Klein, M. (2010) Logistic Regression: A Self-Learning Text. 3rd Edition, Springer, New York. https://doi.org/10.1007/978-1-4419-1742-3

[9] Nassiuma, D. (2000) Survey Sampling: Theory and Methods. Nairobi University Press, Nairobi, 7.

[10] Iannucci, C., Munajo, M. and Sambucini, V. (2011) A System Approach to the Integration of Ecosystem Services with DPSIR Components. Shaker Verlag Aachen.

[11] United States Agency for International Development (2010) Mali Land Tenure Assessment Report. http://www.usaid.gov

[12] Persha, L., Mattingly, D., Greif, A. and Huntington, H. (2014) Impact Evaluation of Land Certification Project in Ethiopia.

https://www.land-links.org/wp-content/uploads/2016/09/USAID_Land_Tenure_EL TAPELAP_IE_Overview_Updated.pdf

[13] Diallo, D. (2014) Properties and Management of Gravelly Soils Developed on Ferruginous Cuirass in Mali. Journal of Soil Science and Environmental Management, 6, 35-43. https://doi.org/10.5897/JSSEM12.084

[14] Jayne, T., Stevens, C., Lowery, S. and Stickler, M. (2016) The Role of Land Policy in 
Agricultural Transformation and Inclusive Economic Growth: Implications for Africa. World Bank, Washington DC.

[15] Kloos, K., McClung, M. and Huang, S. (2016) Insights from Rwanda: Analysis of Land Conflict Resolution Project in Eastern Province. World Bank, Washington DC.

[16] Barthel, K., Cespedes, V., Salazar, B., Torres, R. and Varon, M. (2016) Land and Rural Development Policy Reforms in Colombia: The Path to Peace. World Bank, Washington DC.

[17] Keita, M.M., Ogendi, G.M., Owuor, G. and Wycliff, N.N. (2018) Impacts of Artisanal Gold Mining on Water Quality: A Case Study of Tangandougou Commune in Sikasso Region, Mali. Journal of Environmental Health and Sustainable Development, 3, 621-629. http://dx.doi.org/10.18502/jehsd.v3i4.228

[18] Aggarwal, S. and Freudenberger, M.S. (2013) Tenure, Governance, and Natural Resource Management, Contributions to USAID Development Objectives. http://usaidlandtenure.net/

[19] Keita, M.M., Ogendi, G.M. and Owuor, G. (2018) Socio-economic Factors That Influence Household Incomes in Artisanal Gold Mining Area of Tangandougou Commune, Mali. ADRRI Journal of Agriculture and Food Sciences, 4, 1-19.

[20] Awgichew, S., Flintan, F. and Bekure, S. (2016) Improving Security of Rights to Resources through Participatory Rangeland Management in Ethiopia. World Bank, Washington DC.

[21] Keita, M.M., Owuor, G. and Ogendi, G.M. (2018) Drivers of Participation in Artisanal Gold Mining and Its Effect on Agriculture in Mali. ADRRI Journal of Agriculture and Food Sciences, 4, 1-16. 